\title{
Land use/land cover change prediction in Dak Nong Province based on remote sensing and Markov Chain Model and Cellular Automata
}

\author{
Dự báo thay đổi sử dụng đất/ thảm phủ ở huyện Tuy Đức, tỉnh Đăk Nông dụa \\ vào ảnh vệ tinh và mô hình Markov Chain và Cellular Automata \\ Research article
}

Nguyen Thi Thanh Huong*, Ngo Thi Thuy Phuong

Tay Nguyen University, Dak Lak, Vietnam

\begin{abstract}
Land use and land cover changes (LULCC) including deforestation for agricultural land and others are elements that contribute on global environmental change. Therefore understanding a trend of these changes in the past, current, and future is important for making proper decisions to develop in a sustainable way. This study analyzed land use and land cover (LULC) changes over time for Tuy Duc district belonging to Dak Nong province based on LULC maps classified from a set of multidate satellite images captured in year 2003, 2006, 2009, and 2013 (SPOT 5 satellite images). The LULC spatio-temporal changes in the area were classified as perennial agriculture, cropland, residential area, grassland, natural forest, plantation and water surface. Based on these changes over time, potential LULC in 2023 was predicted using Cellular Automata (CA)-Markov model. The predicted results of the change in LULC in 2023 reveal that the total area of forest will lose 9,031 ha accounting of $50 \%$ in total area of the changes. This may be mainly caused by converting forest cover to agriculture (account for $28 \%$ ), grassland (12\%) and residential area (9\%). The findings suggest that the forest conversion needs to be controlled and well managed, and a reasonable land use plan should be developed in a harmonization way with forest resources conservation.
\end{abstract}

Thay đổi sủ dụng đất và thảm phủ (LULCC) bao gồm cả việc phá rù̀ng để phát triển nông nghiẹp và vì các muc đích khác là tác nhân đóng góp vào biến đổi môi truờng toàn cầu. Vì vậy hiểu biết về khuynh hướng của sự thay đổi này trong quá khứ, hiện tại và tuoong lai là quan trọng để đưa ra những quyết định dúng đắn để phát triển bền vũng. Nghiên cứu đã phân tích LULCC trong thời gian qua dụa vào các bản đồ sử dụng đất và thảm phủ (LULC) đã được phân loại tù một loạt ảnh vệ tinh đa phổ được thu chụp vào năm 2003, 2006, 2009 (ảnh SPOT 5). Nhũng thay đổi LULC theo thời gian và không gian trong khu vưc được phân loại thành đất nông nghiệp với cây dài ngày, cây ngắn ngày, thổ cu, trảng cỏ cây bưi, rùng tư nhiên, rù̀ng trồng và mặt nuớc. Dựa trên sư thay đổi này theo thời gian, LULC tiềm năng cho năm 2023 đã được dụ báo bằng cách sủ dụng mô hình CAMarkov. Kết quả dụ báo LULCC năm 2023 đã cho thấy tổng diện tích rù̀ng bị mất khoảng 9,031 ha chiếm $50 \%$ trong tổng số diện tích thay đổi. Điều này chủ yếu là do chuyển đổi tù̀ rù̀ng tư nhiên sang canh tác nông nghiệp (chiếm 28\%), trảng cỏ cây bụi (12\%) và khu dân cu (9\%). Kết quả cho thấy việc chuyển đổi rùng cần phải được kiểm soát và quản lý tốt và một kế hoạch sư dụng đất hợp lý cần được xây dưng trong sụ hài hòa với bảo tồn tài nguyên rù̀ng.

Keywords: Land Use Land Cover change, SPOT 5 satellite images, CA-Markov, IDRISI Taiga, prediction

\section{Introduction}

Land use and land cover changes are important elements of the problem of global environmental change (Prakasam,
2010). Human actions are altering the terrestrial environment at unprecedented rates, magnitudes, and spatial scales. Land cover change stemming from human land uses represents a major source and a major element of global environmental change (Tunner et al., 1994). Information 
on land use/cover and possibilities for their optimal use is essential for the selection, planning and implementation of land use schemes to meet the increasing demands for basic human needs and welfare. This information also assists in monitoring the dynamics of land use resulting out of changing demands of increasing population (Rawat and Kumar, 2015). Land use affects land cover, and changes in land cover affect land use. Changes in land cover by land use do not necessarily imply degradation of the land. However, many shifting lands use patterns driven by a variety of social causes, result in land cover changes that affects biodiversity, water and radiation budgets, trace gas emissions and other processes that come together to affect climate and biosphere (Riebsame et al., 1994). Land use/cover change detection is very essential for better understanding of landscape dynamic during a known period having sustainable management. Land use/cover change is a widespread and accelerating process, mainly driven by natural phenomena and anthropogenic activities, which in turn drive changes that would impact natural ecosystem (Luna and Robles, 2003; Turner and Ruscher, 2004). There are two ways to collect LULC information as well as LULCC over time: i) information collected from ground surveys and ii) collected from remote sensing. Up to now, satellite imagery data has proven as a useful method in detecting LULCC.

Classification of satellite imagery to produce thematic maps is common in studies related to the use of satellite imagery. Based on LULCC over time to predict LULC in future is also important in planning and managing LULC, therefore, LULC models frequently employ different accessibility measures as a proxy for human influence on land change processes. Of which Markov is a convenient tool for simulating LULC change when changes and processes in the landscape are difficult to describe. A Markov process is one in which the future state of a system can be simulated purely based on the immediately preceding state. Markov model will describe LULC change from one period to another and use this as the basis to project future changes. This is achieved by developing a transition probability matrix of LULC change from time one to time two, which shows the nature of change while still serving as the basis for projecting to a later time period (Logsdon et al.,1996). Based on this approach Quintero et al (2016), Yirsaw et al (2017) used multispectral satellite images and CA-Markov chain model to predict LULC for different regions. The results of these studies have high practical applications in management of LULC. The application of CA-Markov model in the modelling of land use change is due to its ability not only to quantify different states between different land uses, but also to quantify the transition rate between different land uses (Sang et al., 2011). CA-Markov was successful modelled LULC in the future in many studies as Behera et al. (2012), Mishra and Rai (2016), Azizi (2016), Yirsaw et al. (2017), Wang et al. (2016). LULC change analysis is performed using historical land use data produced from satellite images (Yirsaw et al (2017). Driving forces for LULCC change overtime were incorporated to provide an estimate of future scenarios (Behera et al., 2012). The analysis of LULC change from past to future using CA-Markov can play a significant role in land use planning and forest management (Behera et al., 2012; Azizi, 2016; Wang et al., 2016; Yirsaw et al., 2017). Literature reviews show Markov is considered as a suitable method to predict LULC for the future. In Vietnam some authors used Markov model to predict LULC for future (such as Huynh et al.; 2017 [7], Phan et.al; 2017 [14]), however, the predictions were only based on changes of LULC over time without considering the relevant factors as drivers of changes. Furthermore, data analysis for estimates was performed mainly using Microsoft Excel.

The study was carried out in a district of Dak Nong province, Vietnam. Since established in 2003, Dak Nong province experienced loss of a large area of natural forest for expanding urbanization and agricultural cultivation due to the increasing population. In this article, we investigated to analyse and model the LULCC with CA-Markov model by considering some relevant drivers such as distance to road, stream, elevation and slope as factors may effect forest changes. Change detection of LULC was done by using multi-date images for the year 2003, 2006, 2009 and 2013. The LULC was incorporated with the drivers of the changes to build transition probability matrix, then potential LULC in 2023 was predicted using Cellular Automata (CA)-Markov model. Although the changes of LULC in the area was unsustainable due to converting a large area of natural forest to other lands during the last two decades, it has not considered to analysis in a systematically way, simultaneously, the prediction of these changes as a basis for LULC strategies in the future has not been performed in the area. The objective of the study was to analysis LULCC over time and based on the trend of these changes along with relevant factors as drivers of the changes to predict LULC for the future.

\section{Data and methods}

\subsection{Study Area}

The study area (Figure 1) includes the entire district of Tuy Duc. It is located in the West part of Dak Nong province. The spatial extend of the study area is between $1155^{\prime} 55^{\prime}$ " to 12 20' 04 " latitude North and 10712 ' 21 " to 10735 ' 39 "' longitude East.

\subsection{Data Preparation}

The satellite images were used in this study including Spot 5 captured 2003, 2006, 2009 and 2013. These images were pre-processed by previous studies (Nguyen T.T. Huong, $2011,2015)$. The images were projected to UTM 48N, WGS84 to ensure compatibility between images and available digital data.

Additionally, the digital data such as land use maps; training samples collected in the field; and information from Google Earth were employed as training sites in order to classify these images into different LULC.

\subsection{Selection of Drivers (relevant factors)}

The drivers of change in this case are understood as factors that are main contributors to LULC change. Deforestation for agriculture is a big issue in this area. Variables such as 
distance to road, stream can negatively correlate with deforestation (Bax et al., 2015). Topography often has effect on the spread and extent of forest conversion (Bax et al, 2015; Wang et al., 2016). The other factors such as population and precipitation have relationship with LULCC

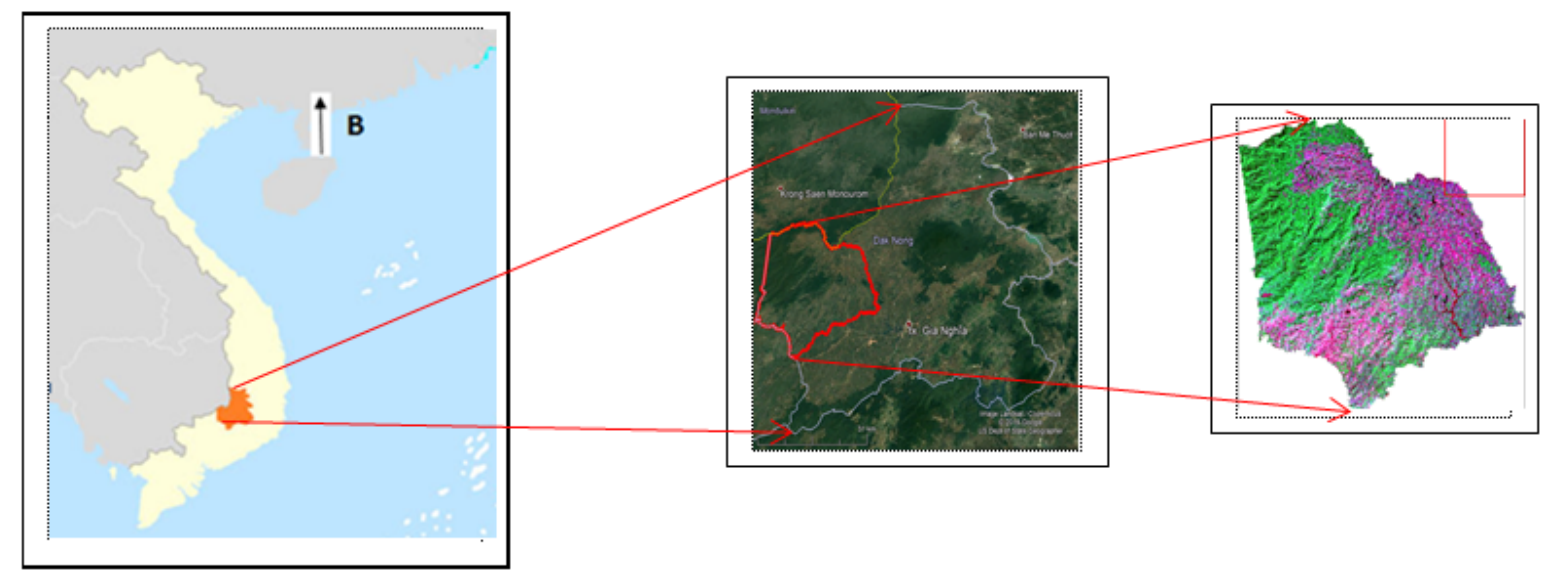

Figure 1. The study site belongs to Tuy Duc district, Dak Nong Province

Elevation and slope were generated from the earth digital elevation models (DEMs) obtained from U.S. Geological Survey. The stream and road map are available in Agricultural Department of Dak Nong province. The factors were divided into 4 or 5 classes as Table 1 . (e.g, Wang et al., 2016), however, due to the lack of available data in the area, the study endeavoured to assess factors which might relate accessibility to forest by human beings. Accordingly, four main factors which are related to approaching forest stands, were concerned in the study; including slope, elevation, distance to roads and streams.
ENVI software version 4.7 was used for image processing. Meanwhile, ArcGIS were employed for database development, spatial data analysis and producing thematic maps. Especially, CA-Markov model was employed to predict future LULC dynamics in the area using a multi-criteria decision-making approach. This task was accomplished using IDRISI Taiga software.

Table 1. Classify of relevant factors affects to the changes land use/land cover

\begin{tabular}{lccccc}
\multirow{2}{*}{ Factors } & \multicolumn{5}{c}{ Class bounds (meter)/(degree) } \\
\cline { 2 - 6 } & class 1 & class 2 & class 3 & class 4 & class 5 \\
\hline Elevation & $<400$ & $400-600$ & $600-800$ & $>800$ & $>30$ \\
Slope & $<15$ & $15-20$ & $20-25$ & $25-30$ & $>1000$ \\
Distance to roads & $<400$ & $400-600$ & $600-800$ & $800-1000$ & $>450$ \\
Distance to stream & $<150$ & $150-300$ & $300-450$ &
\end{tabular}

\subsection{Methods}

\subsubsection{Supervised maximum likelihood classification}

MLC (maximum likelihood classification) method was used to classify the images in this study. One part of data was used to select training areas for the classification process, the other part was employed as an independent reference data for validation. Training areas were distributed throughout the area to ensure the adequate representation of all the classes. The number of training areas was chosen with respect to the size of land cover type. Each image was separately classified. Eight separable land use/cover categories have been identified in this study including (1) perennial agriculture, (2) settlement, (3) grassland, (4) cropland (annual crops), natural forest, plantation forest, and water body. According Congalton and Green (1999), the matrix is the most effective method to evaluate the accuracy. Matrix confusion was produced statistically, which helps evaluating the accuracy of the classification result based on overall accuracy, producer's and user's accuracy as introduced by Congalton and Green (1999).

\subsubsection{Land use/land cover change}

For LULCC analysis, at least there must have two images at two times in the same area. Format of these data should be similar (e.g. vector or raster), simultaneously, they must be projected in the same coordinate projection (e.g. UTM WGS 84). In this study the results of LULC of year 2003, 2006, 2009 were used to analyse LULC changes over time using ArcGIS software.

\subsubsection{Land Use and Land Cover Change Using Markov Chain}

The Markov chain model was used to calculate the amounts of change that may occur to some selected locations in the future (Eastman 2009). The Markov Chains is a stochastic process model that describes the probability of change from one state to another. The transition probability would be the probability that a land cover type (pixels) at the time $t_{0}$ changes to another land cover type in the time $t_{1}$. Therefore, changes in land use among the dates were used to develop a probability transition matrix and then 
predict land uses for a future time. This matrix is the result of the crossing between the images by setting a proportional error. The combination of Markov and Cellular Automata (CA-Markov) allows simulating the evolution of the geographical area represented by pixels. Each pixel can take a value from a finite set of states. All pixels are affected by a transition function that takes as arguments of the measured values and values of the neighbouring pixels as a function of time (Quintero et al. 2016).

In this study, the prediction of LULC was based on two processes including i) Multi criteria evaluation (MCE) to make suitability maps and ii) Markov chain transition probability matrix of LULC types to model LULC for future.

\subsubsection{Multi-criteria evaluation (MCE)}
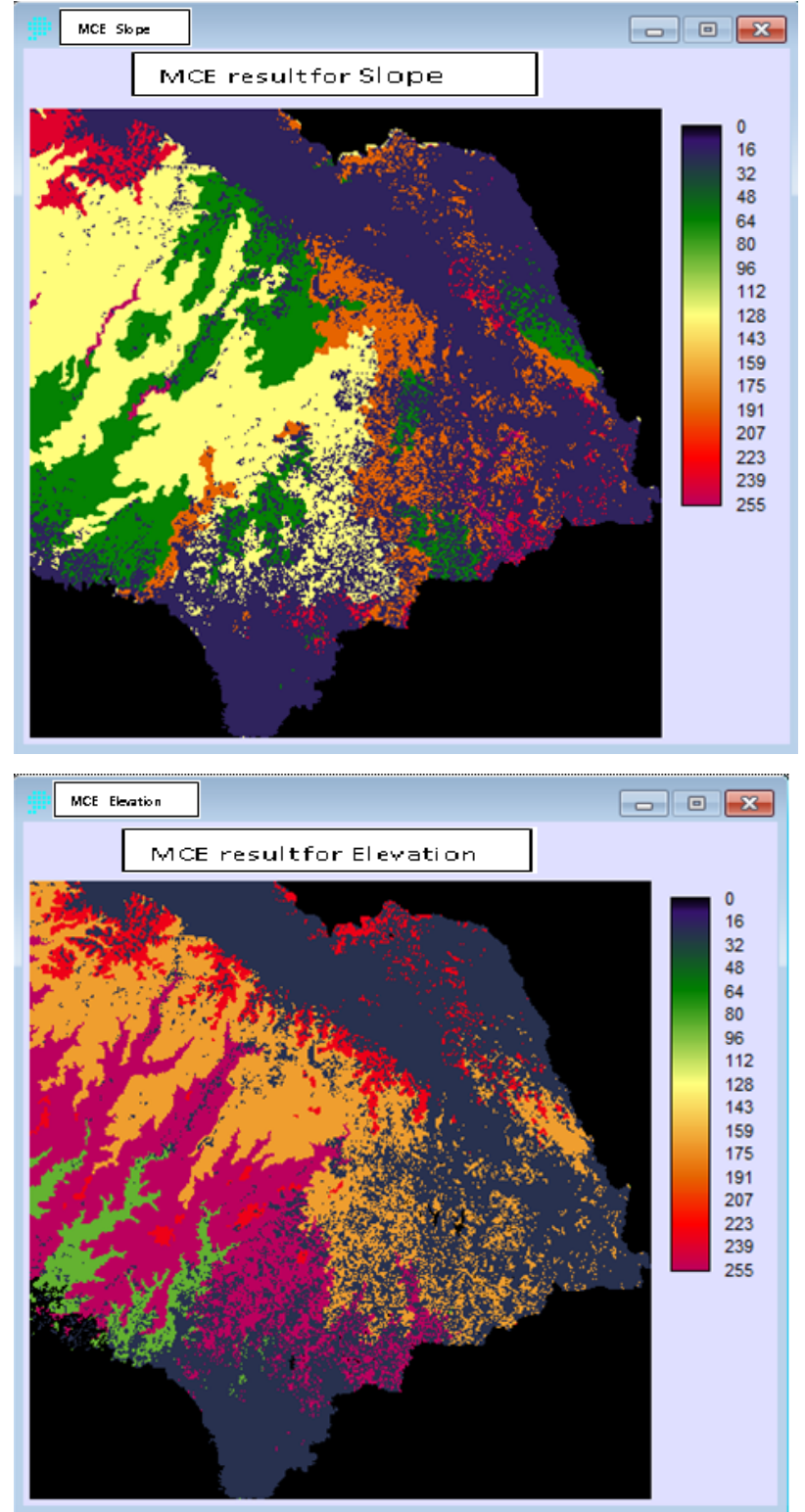

Figure 2. MCE for LULC

As mentioned above, the natural forest is always under risk to convert to other lands, especially agricultural land. To create suitability map (or risk map in this context) of forest conversion, multi-criteria evaluation approach was developed based on different drivers according to their importance, which addressed the past LULC trends for future prediction. Firstly, the areas of natural forest were calculated within the classes of the factors according to periods of 2003 and 2009; thereafter the rate of forest loss for each class was computed. The risk levels of deforesting for each class within the factors were scored based on the rate of forest loss over time. The higher the score expressed the more risk of deforestation. Transition rules were produced for each land cover class through a suitability map built from spatial dependencies and driving forces of change. Suitability maps represent the probability (range from 0 to 255) of a pixel. Each suitability map highlights in which changes are plausible for one land-use category in the future (Houet and Hubert-Moy, 2006).

In the study, LULC was modelled by CA-Markov using IDRISI Taiga software. The scores were assigned to different drivers according to their importance. Based on the scores allocated to drivers; suitability maps for each LULC was produced using MCE that establishes the inherent suitability of each pixel for each LULC type.

For the study area, the transition function was determined based on the difference between 2003 and 2009. Based on these transition matrixes, CA-Markov then used to predict the land cover for 2013 and to simulate land covers in 2023. To determine CA filters, the regular $5 \times 5$ contiguity filter was used as the neighbourhood definition. The transition suitability maps were generated based on the main transitions that occurred among the LULC categories from 2003 to 2013. Then they were used to predict the LULC in 2013 and to simulate the distribution in 2023. Kappa statistics values were used to assess the agreements between the forecasted 2013 LULC map and the actual 2013. The study approaches are summarized in Figure 3.

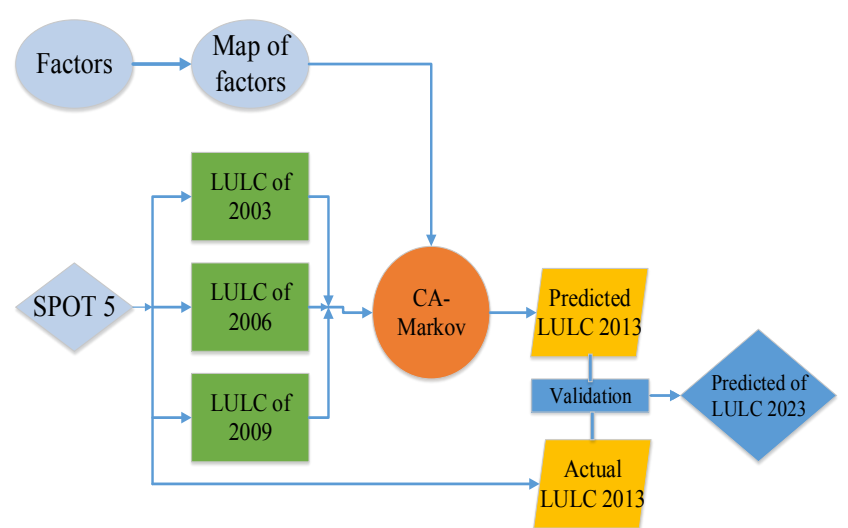

Figure 3. Approaches of the study

\section{Results and discussion}

\subsection{Image classification and accuracy assess- ment}

Three land use/land cover maps were produced, respectively, for years 2003, 2006, and 2009 using the maximumlikelihood algorithm, the values of overall accuracy and Kappa show in Table 2. 
Table 2. Overall accuracy of classified LULC maps

\begin{tabular}{ccc} 
Year & $\begin{array}{c}\text { Overall accuracy (OA) } \\
(\%)\end{array}$ & Kappa \\
\hline 2003 & 71,5 & 0,63 \\
2006 & 84,1 & 0,64 \\
2009 & 87,9 & 0,72
\end{tabular}

Seven types of land use were determined for the study area. They include (1) perennial agriculture, (2) residential area, (3) grass land, (4) crop land, (5) natural forest, (6) plantation forest, and (7) water surface. The land use classification of 2003 presented the largest errors with OA of 71.5 and kappa of 0.63 . The best accuracy was of LULC map of 2009 with OA of 87.9 and kappa of 0.72 . All of them presented the OAs within the range of $71 \%-91 \%$ with kappa within the range of $0.63 \%-72 \%$.

\subsection{LULC change}

The LULC change of the study area during the year 2003 to 2009 was presented in Table 3 and Figure 4. The results of LULC distribution for years 2003, 2006, and 2009 showed that although natural forest area was the dominant land cover class (Table 3 ), there was a significant decreasing trend during the periods, whereas increasing trend was observed for most remaining classes. An insignificant decrease was also found in class of plantation and water surface (Table 3). The highest change was defined in natural forest and cropland in period of 2003 to 2006 with $-36 \%$ and $44 \%$, respectively. Followings were grassland and perennial agriculture with $20 \%$ and $13 \%$, respectively.
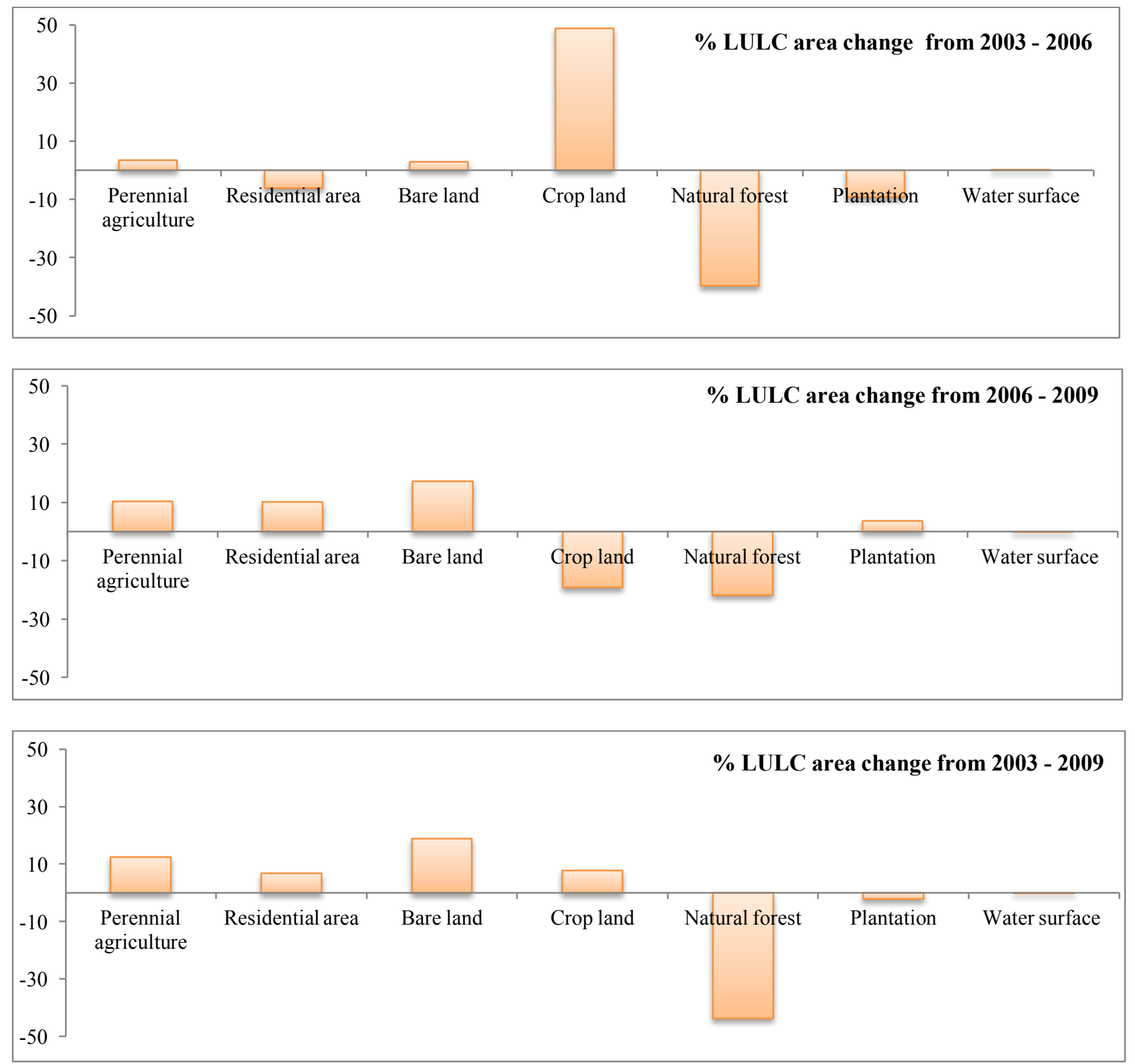

Figure 4. LULC change from 2003-2009 
Table 3. LULC change in periods from 2003 - 2009

\begin{tabular}{lrrrrrr}
\multicolumn{1}{c}{ LULC class } & \multicolumn{2}{c}{$\mathbf{2 0 0 3 - 2 0 0 6}$} & \multicolumn{2}{c}{$\mathbf{2 0 0 6 - 2 0 0 9}$} & \multicolumn{2}{c}{$\mathbf{2 0 0 3 - 2 0 0 9}$} \\
\cline { 2 - 7 } & \multicolumn{1}{c}{ ha } & \multicolumn{1}{c}{$\%$} & ha & \multicolumn{1}{c}{ h } & \multicolumn{1}{c}{ ha } & \multicolumn{1}{c}{ \% } \\
\hline Perennial agriculture & 1027.53 & 3.11 & 4447.3 & 12.45 & 5394.6 & 13.6 \\
Residential area & -1811.16 & -5.49 & 4414.89 & 12.35 & 2943.36 & 7.42 \\
Grass land & 853.48 & 2.59 & 7461.18 & 20.88 & 8123.52 & 20.48 \\
Crop land & 14569.5 & 44.16 & -8308.95 & -23.25 & 3370.99 & 8.5 \\
Natural forest & -11903.8 & -36.08 & -9493.69 & -26.57 & -18893 & -47.63 \\
Plantation & -2781.64 & -8.43 & 1543.96 & 4.32 & -914.87 & -2.31 \\
Water surface & 46.05 & 0.14 & -64.69 & 0.18 & -24.58 & -0.06
\end{tabular}

Changes in LULC have influenced forest distribution in the site study. Rapidly increasing population leading to agricultural land and resident area expanses was the main reason for deforesting the natural forest cover. This is compatible with the fact that Dak Nong province established since 2003, many ethnic groups and other people from other provinces especially from the North of Vietnam migrated to this province. Moreover, the soil in the area is not only suitable for annual crops such as cassava, corn, but also the perennial crops such as coffee, pepper, rubber, and cashew. The inefficient management of forest from functional agencies was also reason for loss of natural forest. In this area, there are always illegal logging and illegal conversion forest to agriculture land.

\subsection{Predicting of LULC change with CA- Markov and validation}

CA-Markov proven as an useful tool to predict future land use/land cover (Behera et al., 2012). In this area, transition matrix of Markov to predict LULC 2013 using LULC map of 2003 and 2009 (Table 5), and the LULC maps of 2003 and 2013 were used to determine transition matrix of LULC 2023 (Table 6). For the model validation, the simulated LULC of 2013 by CA-Markov was compare to actual LULC map. The actual LULC of 2013 was classified using MLK with overall accuracy of $91.1 \%$ (Table 4).

Table 4. Assessing MLK of LULC 2013

\begin{tabular}{lcc} 
LULC class & $\begin{array}{c}\text { Producer's } \\
\text { accuracy }\end{array}$ & $\begin{array}{c}\text { User's } \\
\text { accuracy }\end{array}$ \\
\hline Perennial agriculture & 84.09 & 97.37 \\
Resident area & 90.91 & 90.91 \\
Grass land & 95.12 & 72.22 \\
Crop land & 100 & 100 \\
Natural forest & 81.33 & 100 \\
Plantation & 97.1 & 84.81 \\
Water surface & 95.12 & 98.73
\end{tabular}

Overall accuracy $=91.1 ;$ Kappa $=0.89$

Table 5. Transition matrix of Markov prediction to 2013 based on LULC maps 2003 and 2009

\begin{tabular}{lllllllc}
\multicolumn{1}{c}{ LULC classes } & $\begin{array}{c}\text { Perennial } \\
\text { agriculture }\end{array}$ & $\begin{array}{c}\text { Resident } \\
\text { area }\end{array}$ & $\begin{array}{c}\text { Grass } \\
\text { land }\end{array}$ & Crop land & $\begin{array}{c}\text { Natural } \\
\text { forest }\end{array}$ & Plantation & $\begin{array}{c}\text { Water } \\
\text { surface }\end{array}$ \\
\hline Perennial agriculture & 0.146 & 0.028 & 0.205 & 0.487 & 0.119 & 0.005 & 0.011 \\
Resident area & 0.101 & 0.041 & 0.259 & 0.481 & 0.113 & 0.004 & 0.003 \\
Grass land & 0.083 & 0.047 & 0.292 & 0.483 & 0.088 & 0.004 & 0.003 \\
Crop land & 0.117 & 0.030 & 0.255 & 0.463 & 0.126 & 0.006 & 0.004 \\
Natural forest & 0.076 & 0.016 & 0.064 & 0.252 & 0.581 & 0.004 & 0.007 \\
Plantation & 0.084 & 0.016 & 0.116 & 0.279 & 0.489 & 0.013 & 0.004 \\
Water surface & 0.022 & 0.002 & 0.015 & 0.024 & 0.081 & 0.015 & 0.842
\end{tabular}

Table 6. Transition matrix of Markov prediction to 2023 based on LULC maps 2003 and 2013

\begin{tabular}{llllllll}
\multicolumn{1}{c}{ LULC classes } & $\begin{array}{c}\text { Perennial } \\
\text { agricul- } \\
\text { ture }\end{array}$ & $\begin{array}{c}\text { Resident } \\
\text { area }\end{array}$ & $\begin{array}{c}\text { Grass } \\
\text { land }\end{array}$ & Crop land & $\begin{array}{c}\text { Natural } \\
\text { forest }\end{array}$ & Plantation & $\begin{array}{c}\text { Water } \\
\text { surface }\end{array}$ \\
\hline Perennial agriculture & 0.088 & 0.120 & 0.268 & 0.201 & 0.275 & 0.024 & 0.024 \\
Resident area & 0.108 & 0.100 & 0.269 & 0.201 & 0.289 & 0.024 & 0.010 \\
Grass land & 0.110 & 0.133 & 0.235 & 0.220 & 0.270 & 0.024 & 0.008 \\
Crop land & 0.109 & 0.125 & 0.277 & 0.170 & 0.287 & 0.024 & 0.009 \\
Natural forest & 0.120 & 0.106 & 0.247 & 0.178 & 0.313 & 0.026 & 0.009 \\
Plantation & 0.106 & 0.117 & 0.259 & 0.193 & 0.297 & 0.020 & 0.009 \\
Water surface & 0.018 & 0.012 & 0.034 & 0.022 & 0.070 & 0.007 & 0.837
\end{tabular}


The result was observed that only cropland providing the highest producer's accuracy (100\%) and user's accuracy $(100 \%)$ respectively. The residential area and water surface reached above $90 \%$ producer's accuracy and user's accuracy. The rest ones gained above $80 \%$ both producer's and user's accuracy except for grassland with lowest user's accuracy $(72 \%)$.

In order to validate the LULC prediction given by the CAMarkov model, a comparison was done between the actual LULC area and predicted LULC area of year 2013. The validation of the model was expressed in Table 7 and Figure 5, and the comparison between actual LULC and predicted LULC year 2013 was shown in Table 8.

IDRISI Taiga provides a validation Module that can measure the agreement between two categorical maps. Figure 5 showed how good similarity between forecasted LULC 2013 and classified image 2013 based on Kno (Kappa for no ability), Klocation (Kappa for location) and Kstandard (Kappa index). Kno indicates the proportion classified correctly relating to the expected proportion classified correctly by a simulation with no ability to specify accurately quantity or location. Klocation indicates how well the grid cells are located on the landscape. Kstandard (Kappa index) compares the observed proportion correct to the expected proportion correct due to chance (Pontius, 2000). Kappa is always less than or equal to 1 . A value of 1 means perfect agreement.

The results in Figure 5 indicate that the CA-Markov model with Kappa values $>0.70$. According to Landis and Koch (1977), Kappa value is greater than 0.80 (i.e., 80\%) which represents a strong agreement; a value between 0.40 and 0.80 (i.e., $40 \%-80 \%$ ) represents moderate agreement. This case indicates a moderate to high agreement between two categorical maps. The result represents that there has capability to predict future LULC changes. It is also important to note that the agreeGridcell and agreeQuantity indices can help to understand the predicted results (Wang et al., 2016). The result in Figure 5 (and Table 7), presented DisagreeGridcell is larger than the DisagreeQuantity. This means that the model has a higher ability to predict the LULC changes in quantity than in location in the study area. To reduce the DisagreeGridcell value, more explanatory variables about the location should be considered in further studies (Wang et al., 2016). Table 8 shows that grassland, resident area, cropland, natural forest, and plantation have the best agreement with rate of difference is lower than $10 \%$. Whereas the worst one was from perennial agriculture with different rate from actual LULC reaching $37 \%$, followings were water surface and crop land.

Table 7. Summary of statistics for validation of the CAMarkov model

\begin{tabular}{lc} 
Statistics & Value \\
\hline DisagreeGridcell & 0.1225 \\
DisagreeQuantity & 0.0936 \\
Kstandard & 0.7117 \\
Klocation & 0.8133 \\
Klocationstrata & 0.8133
\end{tabular}

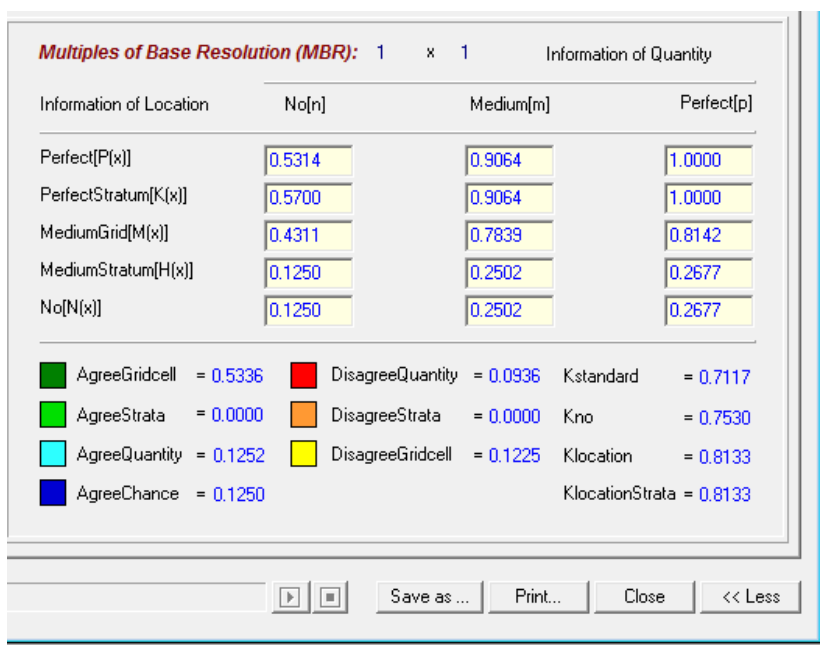

Figure 5. Agreement between actual LULC and projected LULC of year 2013

Table 8. Comparison of actual and projected LULC in 2013

\begin{tabular}{lrrrr} 
& $\begin{array}{c}\text { Actual LULC of } \\
\text { LULC class }\end{array}$ & \multicolumn{2}{c}{$\begin{array}{c}\text { Predicted } \\
\text { LULC of 2013 }\end{array}$} & \multicolumn{2}{c}{$\begin{array}{c}\text { Difference between actual and } \\
\text { predicted LULC }\end{array}$} \\
\cline { 2 - 5 } & (ha) & (ha) & (ha) & \% \\
\hline Perennial agriculture & $7,873.17$ & $10,824.73$ & $-2,951.56$ & -37.49 \\
Resident area & $7,079.31$ & $7,335.07$ & -255.76 & -3.61 \\
Grass land & 17929.05 & $18,295.13$ & -366.08 & -2.04 \\
Crop land & $14,542.38$ & $12,479.00$ & $2,063.38$ & 14.19 \\
Natural forest & $45,146.22$ & $43,398.23$ & $1,747.99$ & 3.87 \\
Plantation & $2,130.87$ & $2,294.33$ & -163.46 & -7.67 \\
Water surface & 335.22 & 409.73 & -74.51 & -22.23
\end{tabular}

The LULC map for the year 2023 (Table 9) was predicted using the LULC maps of 2003 and 2013. The prediction result shows there is probability of land use change with about 18,000 ha in 2023(Table 9). According to Yirsaw et al. (2017), the general trend of LULC changes in the specific area reveals that the changes experienced in the past years are likely to continue in the future. The result in this study is no exception. While an insignificant increasing 
trend for cropland, plantation and water surface is estimated, perennial agriculture is predicted to notably increase in 2023 with nearly $29 \%$ of total area of changes, followed by grassland and residential area with $12 \%$ and $9 \%$, relatively. On the contrary, a decreasing trend can be observed for natural forest area. This class exhibits as the main contribution in area of the change in 2023 (around 50\%) (Table 9 and Figure 6).

Natural forest may be largely replaced by agriculture land and grassland (Table 9). Thus, the ongoing trends of change have placed pressure on natural forest where is the home of biodiversity. The predicted results of the change in LULC in 2023 reveal that the total area of forest would lose 9,031 ha accounting of $50 \%$ in total area of the changes. This is mainly caused by converting forest to agriculture (account for $28 \%$ ), grassland (12\%) and residential area $(9 \%)$. The findings suggest that the forest conversion needs to be controlled and well managed, and a reasonable land use plan should be developed in a harmonization way with forest resources conservation.

Table 9. LULC area change from for $\mathbf{2 0 2 3}$

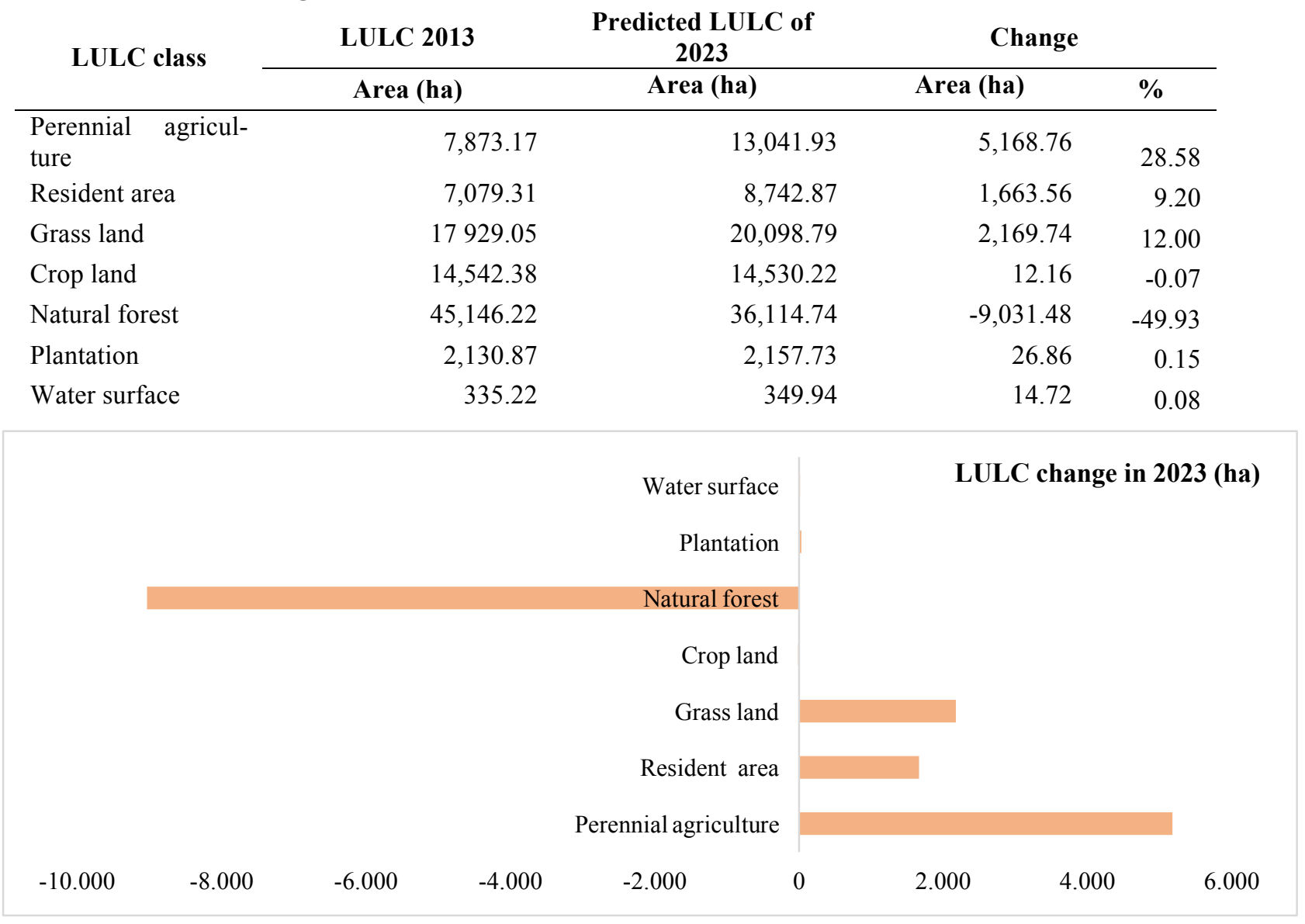

Figure 6. LULC change is predicted for year 2023

\section{Conclusions}

The LULC maps in Tuy Duc district were produced based on SPOT 5 satellite images captured in 2003, 2006, and 2009 with OA ranging 71,5\% - 87,9\% and kappa varying from $0.63-0.72$.

The predicted LULC 2013 using CA-Markov model, which was based on LULC maps of 2003 and 2009 and relevant factors, was compared to the actual LULC 2013. The validation of predicted LULC and classified LULC shows a moderate to high agreement between the prediction LULC 2013 with the actual data of the base year (2013). This reveals that CA-Markov is an appropriate model for predicting future LULC change.

The analysis of LULC change shows natural forest has been decreasing and the predictions show this cover would continue reducing in the future. The projected results of LULC year 2023 indicates that total area of natural forest would dramatically decrease (about 9,000ha).

The decrease may primarily be caused by increasing population and expanding residential area, leading need of land for agriculture (presented in Table 9). Furthermore, replacing a large area of natural forest by grassland would be also the result of forest decreasing.

Acknowledgement: We thank PEER Program for financial supporting the graduate studies of the second author of this manuscript. We also thank Mr. Vu Y Dinh, graduate student of the Tay Nguyen University for his valuable assistance on the analysis of the data. 


\section{References}

[1] Azizi A., Malakmohamadi B. and Jafari H.R., 2016. Land use and land cover spatiotemporal dynamic pattern and predicting changes using integrated CAMarkov model. Global J. Environ. Sci. Manage., 2(3): 223-234, doi: 10.7508/gjesm.2016.03.002.

[2] Bax V., Francesconi W. and Quintero M. 2015. Spatial modeling of deforestation processes in the Central Peruvian Amazon. Journal for Nature Conservation 29: 79-88.

[3] Behera, M. D., Santosh N Borate, Sudhindra N Panda, Priti R Behera2 and Partha S Roy3, 2012. Modelling and analysing the watershed dynamics using Cellular Automata (CA)-Markov model - A geo-information based approach. J. Earth Syst. Sci. 121(4): 1011-1024

[4] Congalton, R. G. and Green K., 1999. Assessing the accuracy of remotely sensed data: Principles and practices, Boca Raton, Lewis Publishers.

[5] Eastman, J.R., 2009. IDRISI Taiga, Guide to GIS and Remote Processing; Clark University: Worcester, MA, USA, 2009.

[6] Houet T. and Hubert-Moy L., 2006. Modelling and projecting land-use and land-cover changes with Cellular Automation considering landscape trajectories: An improvement for simulation of plausible future states. EARSeL Proceedings, European Association of Remote Sensing Laboratories, 5(1): 63-76.

[7] Huynh, V.C., Chau, V.T.T., and Huynh, C.H. 2017. Study and prediction of land use change in Nha Trang, Khanh Hoa province using Markov and GIS (Nghiên cứu và dự báo biến động sử dụng đất tại thành phố Nha Trang, tỉnh Khánh Hòa ứng dụng trong chuỗi Markov và GIS). Journal of Agricultural Science \& Technology 1: 37-46.

[8] Landis, R.J. and Koch, G. G. 1977. The measurement of observer agreement for categorical data. Biometrics 33(1): 159-174.

[9] Logsdon M.G, Bell E.J., and Westerlund F.V., 1996. Probability mapping of land use change: a GIS interface for visualizing transition probability. Compute Environ Urban Syst. 20: 389-398.

[10] Luna, R. and Robles, B., 2003. Land use, land cover changes and coastal lagoon surface reduction associated with urban growth in northwest Mexico. Landscape Ecology 18(2): 159-171.

[11] Mishra, V. N. and Rai, P. K., 2016. A remote sensing aided multi-layer perceptron-Markov chain analysis for land use and land cover change prediction in Patna district (Bihar), India. Orginal Paper, Arab J Geosci. 9:249, doi: 10.1007/s12517-015-2138-3.

[12] Nguyen T.T. Huong. 2015. Topographic correction for differential illumination effects on SPOT 5 satellite imagery. No. 14 June 2015, Journal of Science. ISSN 1859-4611. Tay Nguyen University.
[13] Nguyen, T.T. Huong. 2011. Forestry Remote Sensing, Using Multi - data source for inventory of natural broad - leaved evergreen forests in the Central Highlands of Vietnam. Lambert Academic Publishing. $165 \mathrm{Pp}$.

[14] Phan, H.V., Pham T.V, Tran. C.T., and Vo, Q.M. 2017. Application of Markov and GIS to assess and predict land use change. (Ứng dụng hệ thống thông tin địa lý và chuỗi Markov trong đánh giá biến động và dự báo nhu cầu sử dụng đất đai). Scientific Journal of Can Tho University. Special subject: Information technology. Pp 119-124

[15] Pontius, R.G., 2000. Quantification error versus location error in comparison of categorical maps. Photogrammetric Engineering and Remote Sensing 66(8): 1011-1016.

[16] Prakasam, C., 2010. Land Use and Land Cover Detection through Remote Sensing. Approach: A Case Study of Kodaikanal taluk, Tamilnadu. International Journal of Geometics and Geosciences, 1(2): 150158.

[17] Quintero G. V., Moreno R. S., García M. P., Guerrero F. V., Alvarez C. P. and Alvarez A. P., 2016. Detection and Projection of Forest Changes by Using the Markov Chain Model and Cellular Automata. Sustainability, 8(3): 1-13.

[18] Rawat, J.S., Kumar, M., 2015. Monitoring land use/cover change using remote sensing and GIS techniques: A case study of Hawalbagh block, district Almora, Uttarakhand, India, Egypt. J. Remote Sensing Space Sci. 18(1): 77-84.

[19] Riebsame W.E., Meyer W.B., Turner B.L., 1994. Modeling Land Use and Cover as Part of Global Environmental Change. In: Frederick K.D., Rosenberg N.J. (eds) Assessing the Impacts of Climate Change on Natural Resource Systems. Springer, Dordrecht.

[20] Sang L., Zhang C., Yang J., Zhu D. and Yun W., 2011. Simulation of land use spatial pattern of towns and villages based on CA-Markov model. Math. Comput. Model., 54(3): 938-943.

[21] Turner B.L.II., Meyer W.B., Skole. D.L., 1994. Global Land-Use/Land-Cover Change: Towards an Integrated Study. Ambio, 23(1): 91-95.

[22] Turner, M.G and Ruscher, C.L., 2004. Change in landscape patterns in Georgia, USA. Ecol. 1(4): 251421.

[23] Wang, W., Zhang C. Allen J.M., Li W., Boyer M.A., Segerson K., John A and Silander Jr., 2016. Analysis and Prediction of Land Use Changes Related to Invasive Species and Major Driving Forces in the State of Connecticut. Land 5(3): 25.

[24] Yirsaw, E., Wu W., Shi X., Temesgen H. and Bekele B., 2017. Land Use/Land Cover Change Modeling and the Prediction of Subsequent Changes in Ecosystem Service Values in a Coastal Area of China, the Su-Xi-Chang Region. Sustainability 2017, 9(7), 1204. doi: 10.3390/su9071204. 